\title{
Farmers and Agricultural Extension Officers Perception of Striga gesnerioides (Willd.) Vatke Parasitism on Cowpea in the Upper East Region of Ghana
}

\author{
Peter Haruna $\left(\mathbb{D},{ }^{1}\right.$ Aaron T. Asare $\mathbb{C D}^{1},{ }^{1}$ Elvis Asare-Bediako $\mathbb{D}^{2},{ }^{2}$ and Francis Kusi ${ }^{3}$ \\ ${ }^{1}$ Department of Molecular Biology and Biotechnology, University of Cape Coast, Cape Coast, Ghana \\ ${ }^{2}$ Department of Crop Sciences, University of Cape Coast, Cape Coast, Ghana \\ ${ }^{3}$ Savannah Agricultural Research Institute (SARI), P.O. Box 46, Manga Station, Bawku, Ghana \\ Correspondence should be addressed to Aaron T. Asare; aasare@ucc.edu.gh
}

Received 15 February 2018; Accepted 29 May 2018; Published 5 August 2018

Academic Editor: Clifford Gold

Copyright (c) 2018 Peter Haruna et al. This is an open access article distributed under the Creative Commons Attribution License, which permits unrestricted use, distribution, and reproduction in any medium, provided the original work is properly cited.

\begin{abstract}
Cowpea [Vigna unguiculata (L.) Walp] is an important food security crop in Sub-Saharan Africa. However, cowpea production in some parts of this region is constrained by Striga gesnerioides (Willd.) Vatke infestation resulting in yield losses. This study assessed the farmers and agricultural extension officers (AEOs) perception of S. gesnerioides parasitism on cowpea in the Upper East Region of Ghana. In all, 200 respondents-179 cowpea farmers and 21 AEOs-in five cowpea growing districts were randomly sampled to answer closed- and opened-ended questions coupled with visit to cowpea farms. Majority of the farmer respondents were males between the ages of 21 and 60 with very little or no formal education. Almost all of the respondents could identify the parasitic weed, S. gesnerioides, but they lacked adequate knowledge of the parasitic effects on the host, cowpea plant. S. gesnerioides infestation was widespread and devastating in almost all the fields surveyed. Its effects on the host plants (cowpea) included stunted growth, leaf senescence, chlorosis, death of the crop, and reduced yield. Different management strategies employed by the farmers to contain the spread of the parasite include weeding (90\%), application of manure (5.5\%), and crop rotation and fallowing (4.0\%). Both farmers and extension officers had very little knowledge on existence of $S$. gesnerioides resistant cowpea genotypes for cultivation. Farmers expressed the desire to cultivate Striga-resistant cowpea varieties when made accessible, since it is the most reliable and environmentally friendly method of controlling the parasitic weed.
\end{abstract}

\section{Introduction}

Cowpeas [Vigna unguiculata (L.) Walp] is one of the most important grain legume crops mostly grown in the tropics and has tolerance to high temperatures and drought. Cowpea is important in human dietary need, especially for resourcepoor families, as a source of quality protein for human and animal nutrition. It contributes more towards alleviating the problem of protein-energy malnutrition in children under 5 years old in the predominantly carbohydrates based diet societies [1]. Cowpea grains contain $23.4 \%$ protein, $1.8 \%$ fat, and $60.3 \%$ carbohydrates and it is a rich source of calcium and iron $[2,3]$.

Cowpea is used in controlling soil erosion due to its tendency to produce a heavy vegetative growth that provides full ground cover. As a leguminous crop, its root system has high ability of associating with the different species of Rhizobia bacteria in the soil to fix atmospheric nitrogen. It fixes about $70-240 \mathrm{~N} \mathrm{~kg} \mathrm{ha}^{-1}$ of atmospheric nitrogen per year and residue of fixed $\mathrm{N}$ deposit of $60-70 \mathrm{~N} \mathrm{~kg} \mathrm{ha}^{-1}$ can be left to the soils for the successive crop [4]. As a result of this, cowpeas are grown in rotation or mixed with many cereals and tuber food crops. Cowpea is also a source of income for many rural household families in Ghana who are dependent on agricultural employment through cultivation of the crop, processing, and sales of cowpea products though in relatively small quantities [5].

In Ghana, cowpea is second to groundnut in terms of area under cultivation and quantity produced and consumed annually [6]. An average of 143,000 MT is produced annually on about 156,000 ha making Ghana the fifth highest producer of cowpea in Africa [7]. The Guinea savannah zone of Ghana 
(Northern and Upper West Regions) is the major production area in the country [8]. Other production areas include Sudan savannah zone (Upper East Region) and some districts in the transitional zones of Brong Ahafo and Ashanti Regions.

Cowpea production in Ghana is constrained by the parasitic weed, Striga gesnerioides (Willd.) Vatke, which attaches to the roots of the host plants and diverts assimilates and photosynthate from roots and hence causes reduction of the total biomass and yield $[9,10]$. S. gesnerioides is reported as one of the leading biohazards to agricultural productivity in Africa [11]. This parasitic weed represents a critical danger to cowpea production especially in the three regions of Northern Ghana [12]. Cowpea yield is reduced because of S. gesnerioides infestation and this could be up to $70 \%$ dependent upon the degree of harm and level of infestation $[13,14]$. It has been reported that susceptible cultivars could record yield losses of $100 \%$ when S. gesnerioides population was more than 10 plants for each host plant [15]. Notably, yield reduction brought about by $S$. gesnerioides in dry savannah of Sub-Saharan Africa is evaluated in millions of tons every year and the spread of the parasite is relentlessly expanding [16].

The harm caused by S. gesnerioides occurs at different parts of cowpea plants [17] influencing the physiological and biological processes of the crop. Decreased leaf area, photosynthesis, inadequate blooming and podding, and reduced seed advancement have been reported [17]. Such harm is frequently escalated by transpiration of the parasite when dry spell predominates. Once a field is invaded by S. gesnerioides, the underground $S$. gesnerioides seed stock will build up $[18,19]$, which sets up a situation of potential yield loss in the future [20].

The areas affected by $S$. gesnerioides comprise West and Southern Africa, India, Asia or Europe, and USA [21]. In West Africa, S. gesnerioides has been reported to occur in Benin, Burkina Faso, Mali, Nigeria, Niger, Ghana, Togo, and Cameroon with different races of the parasite designated to each country [20]. These races were assigned as SG1 (Burkina Faso), SG2 (Mali), SG3 (Nigeria and Niger), SG4 and SG4z (Benin), SG5 (Cameroon), and SG6 (Senegal) [22]. The past studies have not examined parasite from Ghana leaving its phylogenetic position and damage range unknown. However, [23] suggested that the Ghanaian form of $S$. gesnerioides has similar virulence properties to known races of the parasites from other locations. The problem of S. gesnerioides infestation appears to be widely spread in the three northern regions of Ghana which affects cowpea production.

Management of this parasitic weed, S. gesnerioides, is very pertinent in order to improve yield and production of cowpea in the northern regions of Ghana. It has been indicated that, in the Sudan savannah zone of Ghana, Striga infestation is very significant and that an average number of 9,384 seeds $\mathrm{m}^{-2}$ were found in the land that had been recultivated after fallow [24]. Information on the farmers' and extension officers' awareness and management strategies is an important prerequisite for developing effective protocol to control this parasitic weed. Such useful information is however limited in Ghana. Therefore, this study was undertaken to assess farmers' and AEOs' perception of S. gesnerioides infestations on cowpea production in the Upper East Region of Ghana.

\section{Materials and Methods}

2.1. Study Area. The Upper East Region (UER) of Ghana lies between longitude $1015^{\prime} \mathrm{W}$ and $005^{\prime} \mathrm{E}$ and stretches from latitude $10030^{\circ} \mathrm{N}$ to $1108^{\circ} \mathrm{N}$. The region lies in the Sudan savannah agroecology, which forms the semi-arid part of Ghana. The area is part of what is sometimes referred to as interior savannah and is characterized by level to gently undulating topography [25]. The region has alternating wet and dry seasons with the wet season occurring between June and October during which about $95 \%$ of rainfall occurs. Maximum rainfall occurs in August, and severe dry conditions exist from November to May each year. Annual rainfall ranges from 800 to $1200 \mathrm{~mm}$. There is wide fluctuation in relative humidity $(\mathrm{RH})$ with $25 \%$ in dry season and above $75 \%$ in the wet season.

The study was carried out in five districts in the Upper East Region of Ghana from August to September, 2016. The districts were Binduri, Builsa South, Garu-Tempane, Kassena-Nankana Municipal, and Talensi. These districts are major cowpea producing centres in the Upper East Region of Ghana.

2.2. Sampling Strategy. Information was generated from 200 respondents made of 179 cowpea farmers and 21 agricultural extension officers (AEOs) from 14 communities in 5 main cowpea production districts. Only the major cowpea production communities in these districts were considered, and farmers with at least one-year experience in cowpea cultivation were selected to respond to the questionnaire. The selection of the districts, communities, and farmers for the study was in consultation with the regional crop officer, district crop officers, and agriculture extension officers of the Ministry of Food and Agriculture (MoFA), respectively. One cowpea farm was selected in each community in consultation with the AEO to assess the extent of S. gesnerioides infestation.

2.3. Instruments. The research tools employed were farm visitations and the administration of both closed- and openended questionnaires. The questionnaire captured demographic information, farm characteristics, knowledge on $S$. gesnerioides, control and management of S. gesnerioides, and knowledge on Striga-resistant cowpea varieties. One hundred and seventy-nine (179) cowpea farmers and 21 agricultural extension officers in the five cowpea growing areas responded to set of questionnaires to assess their perception on Striga infestation on cowpea production in the Upper East Region (Table 1).

\section{Results}

3.1. Demography. Majority of the farmer respondents $(60.9 \%)$ were males between the ages of 21 and $60(85.5 \%)$, with no formal education (63.1\%) (Figures 1-3). Only 36.9\% of the respondents had some formal education, ranging from primary to tertiary. However, majority of the farmers $(57.5 \%)$ 
TABLE 1: The districts, communities, and number of respondents for the survey.

\begin{tabular}{|c|c|c|c|c|}
\hline District & Communities & Number of farmers & Number of extension officers & Number of respondents \\
\hline \multirow{3}{*}{ Binduri } & Kumpalgoga & 12 & \multirow{3}{*}{4} & \multirow{3}{*}{40} \\
\hline & Tambigu & 12 & & \\
\hline & Tansia & 12 & & \\
\hline \multirow{3}{*}{ Builsa South } & Gbedembilisi & 12 & \multirow{3}{*}{4} & \multirow{3}{*}{40} \\
\hline & Uwesi & 12 & & \\
\hline & Wiasi & 12 & & \\
\hline \multirow{2}{*}{ Garu-Tempane } & Gosieko & 14 & \multirow{2}{*}{4} & \multirow{2}{*}{39} \\
\hline & Konkomada & 21 & & \\
\hline \multirow{3}{*}{ Kassena-Nankana Municipal } & Bonia & 12 & \multirow{3}{*}{4} & \multirow{3}{*}{40} \\
\hline & Nayagenia & 12 & & \\
\hline & Wuru & 12 & & \\
\hline \multirow{3}{*}{ Talensi } & Balungu & 12 & \multirow{3}{*}{5} & \multirow{3}{*}{41} \\
\hline & Gbeo & 12 & & \\
\hline & Winkongo & 12 & & \\
\hline
\end{tabular}

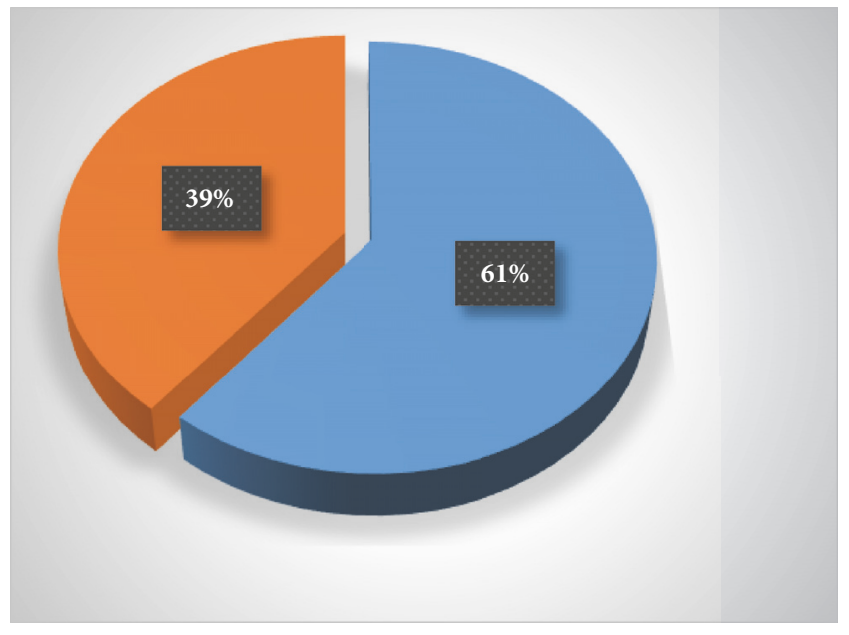

Male

Female

FIGURE 1: Gender distribution of the farmers.

had 1-5 years of farming experience in cowpea cultivation (Figure 4).

All the agricultural extension officers (AEOs) who responded to the questionnaire in the current study were males, ranging from 21 to 56 years. Most of them had a Higher National Diploma (HND) (47.6\%) and a bachelor degree $(33.3 \%)$ and with 1-35 years of working experience (Figures 5-7).

3.2. Knowledge of S. gesnerioides. All the farmers interviewed in this study call both $S$. gesnerioides and S. hermonthica (Del.) Benth., which is a cereal parasite, by the same local name. The names (these are generic without species distinction) given to Striga spp. in the various languages in the Upper East Region of Ghana are indicated in Table 2. On the whole, $99.4 \%$ of the respondents knew the parasitic weed, S. gesnerioides. About $41.9 \%$ of the farmers had knowledge

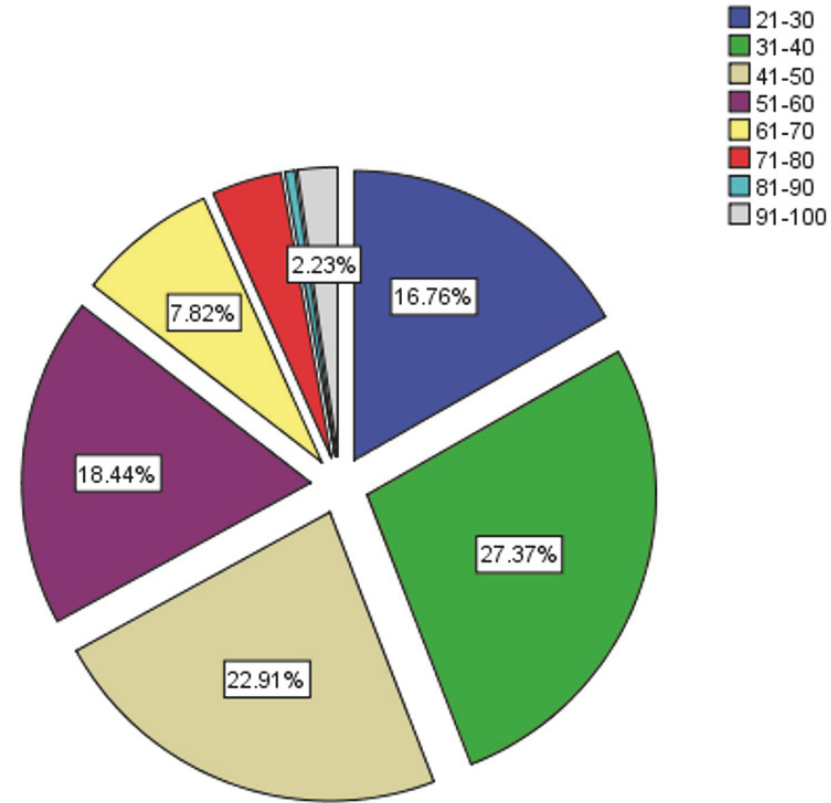

FIgURE 2: Age distribution of the farmers.

that the parasite affects only cowpea and $44.7 \%$ said it affects cowpea, maize, millet, and sorghum (Figure 8 ). The majority of the farmers $(58.1 \%)$ therefore indicated that $S$. gesnerioides affects cowpea and other cereals such as maize, millet, and sorghum (Figure 8). Farmers were of the view that $S$. gesnerioides and $S$. hermonthica were the same plant just that $S$. gesnerioides is the male Striga and S. hermonthica is the female Striga (Figure 9).

Only $19 \%$ of the farmers knew that the Striga gesnerioides attaches to the roots and draws water and nutrients from the host plants. The rest of them, even though they knew that $S$. gesnerioides was a plant parasite, did not know the mechanism it employs to attack its host plants. Most of the farmers knew that $S$. gesnerioides grows close to the host plant but has no knowledge of how it affects the host. 
TABLE 2: Generic names of Striga spp. in various languages in Upper East Region of Ghana.

\begin{tabular}{lccc}
\hline S/N & Language & People & Names of Striga spp. \\
\hline 1 & Kasen & Kasena & 'Zongor' \\
2 & Buili & 'Yung' \\
3 & Frafra & Frailsa & 'Wombile'/'Wolim' \\
4 & Kusal & Kusalsi & 'Wang' \\
5 & Moa & Bimoba & 'Yubong' \\
\hline
\end{tabular}

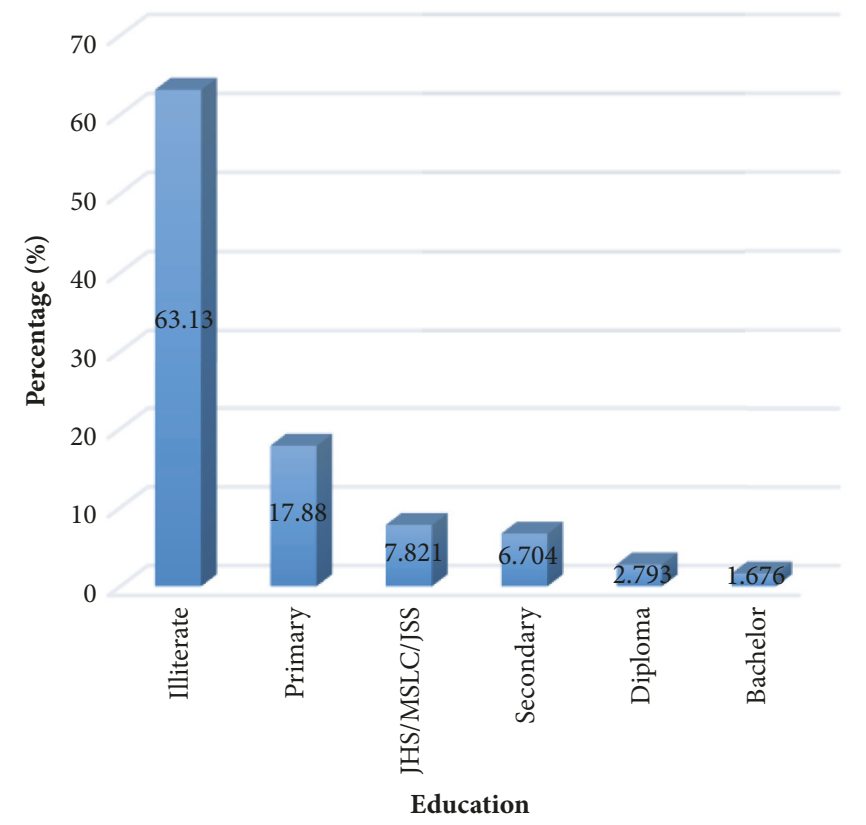

FIGURE 3: Educational qualifications of farmers.

Majority of the farmers said that the $S$. gesnerioides emerges close to the flowering stage of the host plants and the severity of the effect on the host plants is seen at the fruiting stage of the plants. According to the farmers, symptoms exhibited by host plants due to S. gesnerioides' infestation include stunted growth, poor yield, and sometimes death of the host plant. Over $90 \%$ of the farmers observed that the parasitic weed severely infests their cowpea plants, resulting in yield loss of about $81-100 \%$ (70.9\%). Consequently, some farmers are abandoning cowpea production.

All the AEOs had knowledge of S. gesnerioides as parasitic plant. According to them, the weed was very common in most farms within their areas of supervision. Despite the fact that the AEOs know that $S$. gesnerioides was a parasitic weed, most of them did not actually know the crop it affects (host). Only three (3) of the AEOs representing $14.3 \%$ knew that $S$. gesnerioides affects cowpea and not cereals. The AEOs who knew the host crop of the parasitic weed were mostly from the Kassena-Nankana Municipal. The rest of the eighteen (18) AEOs representing $85.7 \%$ said the parasitic weed, $S$. gesnerioides, affects cowpea, maize, millet, sorghum, and rice (Table 3).

More than $80 \%$ of the extension officers did not know the mechanism employed by the $S$. gesnerioides to attack its

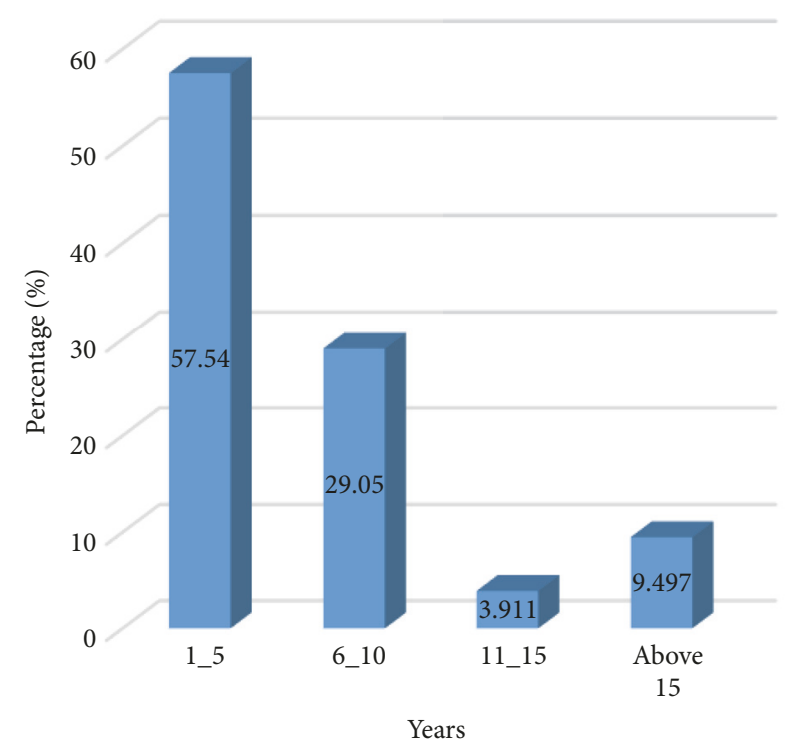

FigURE 4: Number of years farmers have been cultivating cowpea.

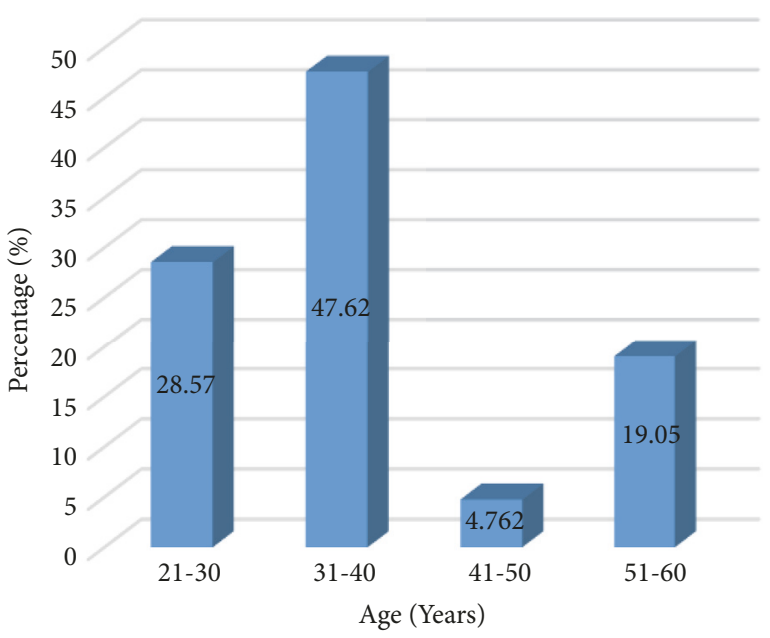

FIGURE 5: Ages of agricultural extension officers (AEOs).

host. Only 19\% of them could explain that the S. gesnerioides attaches to the roots of the host plants and draws nutrient and water causing severe effects on the hosts (Figure 10). Most of them just mentioned some of the symptoms on the host plants but not the mechanism involved. Some of the symptoms they mentioned included stunted growth, poor yield, death, and yellowing of leaves of host plant. 


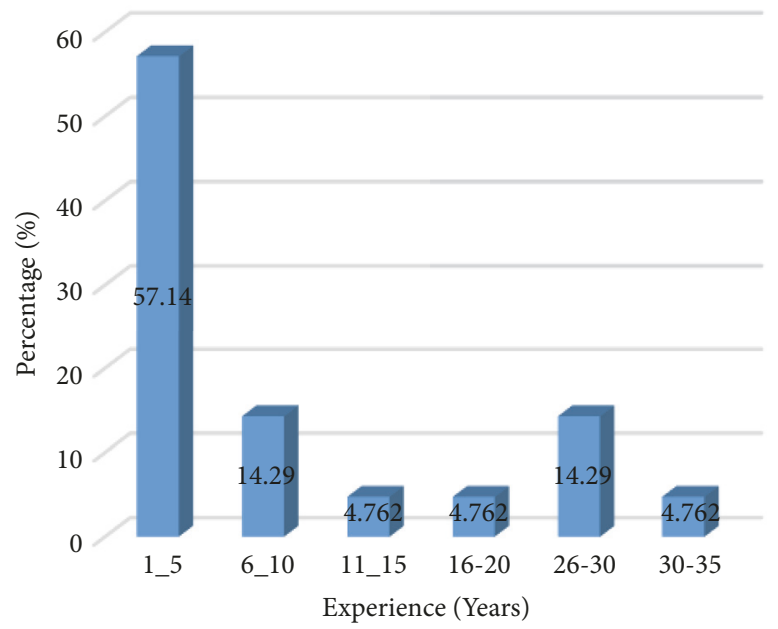

FIGURE 6: Number of years of experience of agricultural extension officers (AEOs).

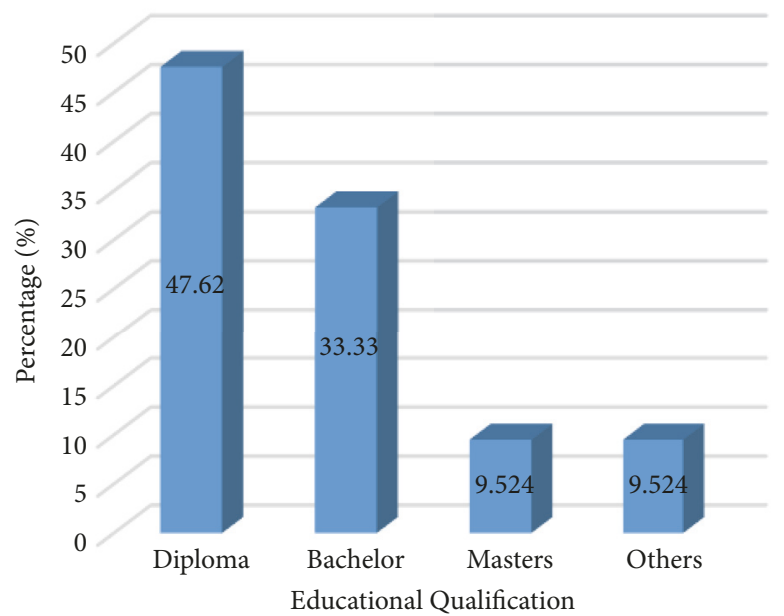

FIgURE 7: Educational qualification of the agricultural extension officers (AEOs).

TABLE 3: Responses of agriculture extension officers on crops affected by $S$. gesnerioides.

\begin{tabular}{lcc}
\hline Crops & Number of AEOs & Percent $(\%)$ \\
\hline Cowpea & 3 & 14.3 \\
More than one crop & 18 & 85.7 \\
Total & 21 & 100.0 \\
\hline
\end{tabular}

The majority (61.9\%) of the AEOs observed that the degree of effect of $S$. gesnerioides on the host plants was severe; $23.8 \%$ viewed the effect as moderate, $0.52 \%$ viewed the effect as minimal whilst the other $4.75 \%$ viewed it as variable, depending on the number of the parasitic weeds per plant per field (Figure 11). The higher the number of S. gesnerioides per plant, the more severe the effect on the crop's growth and yield.

3.3. Management and Control of the Parasitic Weeds. The majority (90\%) of the farmers control the parasite only by

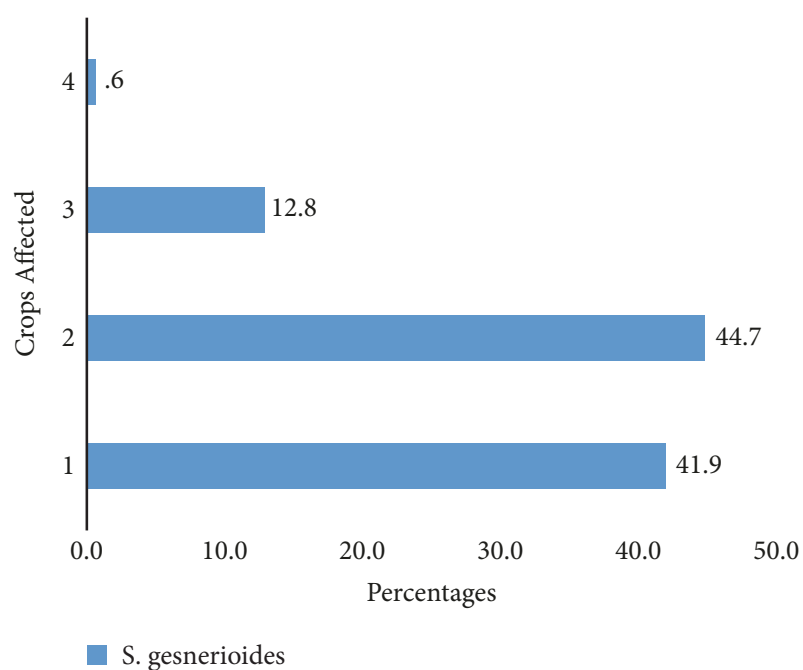

Figure 8: Farmers' responses on the crop species affected by $S$. gesnerioides. 1: cowpea only; 2: cowpea and cereals (maize, millet, and sorghum); 3 : other crops either than cowpea (maize, millet, and sorghum); 4: no response.

TABLE 4: Mode of control of S. gesnerioides in Upper East Region.

\begin{tabular}{lcc}
\hline Method & Frequency & Percentage (\%) \\
\hline Weeding/Hand picking & 180 & 90 \\
Using Organic Matter & 11 & 5.5 \\
Spraying with Herbicides & 1 & 0.5 \\
Others & 8 & 4.0 \\
Total & 200 & 100 \\
\hline
\end{tabular}

weeding or hand picking. Only 5.5\% of them said they used organic manure and $4.0 \%$ used crop rotation to manage the weeds (Table 4). However, farmers stated that the cultural methods used to control S. gesnerioides were not effective and it may take longer time (about 5-20 years) to control the weeds.

Indeed, $68 \%$ of the farmers submitted that the most effective way to combat the devastating effects of $S$. gesnerioides in their farms is to cultivate cowpea varieties that are resistant to the parasitic weed in the region since the cultural methods are not effective and sustainable. Only $12 \%$ said that the use of organic manure is the most effective way of controlling the parasitic weed since they were of the view that there are no resistant cowpea varieties to control the parasite (Figure 12).

3.4. Awareness of S. gesnerioides Resistant Cowpea for Cultivation. Only a few farmers (12\%) had knowledge of the existence of $S$. gesnerioides resistant cowpea varieties in the Upper East Region of Ghana whilst the majority (88\%) of them had no knowledge (Figure 13). Only $22.7 \%$ of those who were aware of the S. gesnerioides resistant cowpea had ever cultivated the resistant cowpea variety called IT97K-499-35 (Songotra). Majority of the farmers who were aware of $S$. gesnerioides resistant cowpea varieties were from the Binduri (36.4\%) and Talensi (27.3\%) districts (Figure 14). 


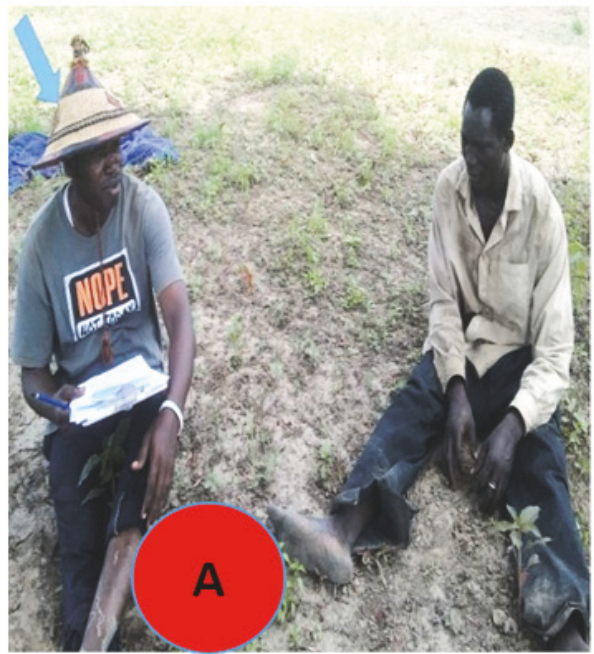

(a)

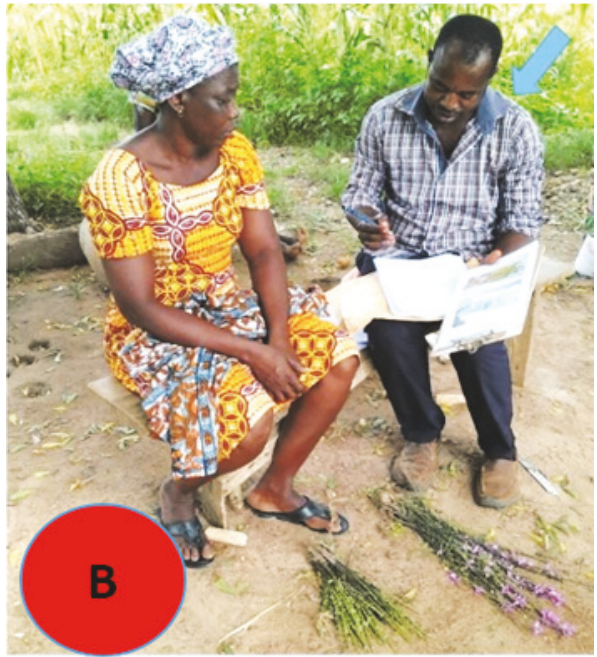

(b)

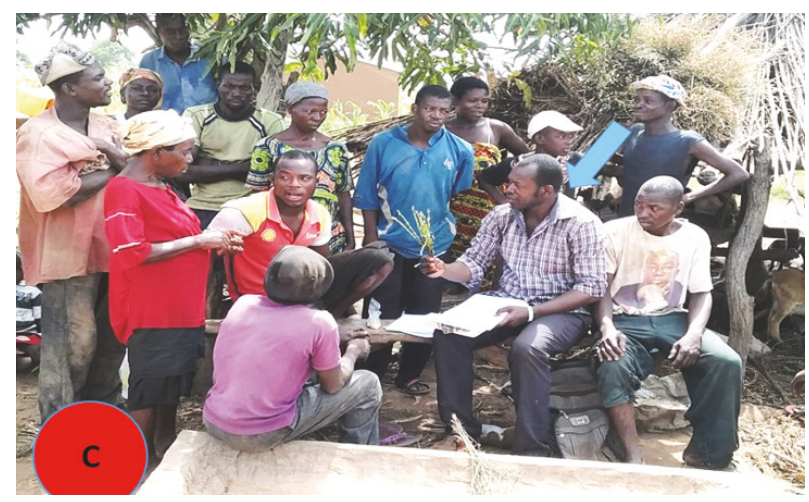

(c)

FIgURE 9: Administering questionnaire to a male farmer in the Kasesna-Nankana Municipal (a); a female farmer in the Builsa South district (b); a discussion session on Striga with some cowpea farmers in the Builsa South district of the Upper East Region (c) (arrow on researcher).

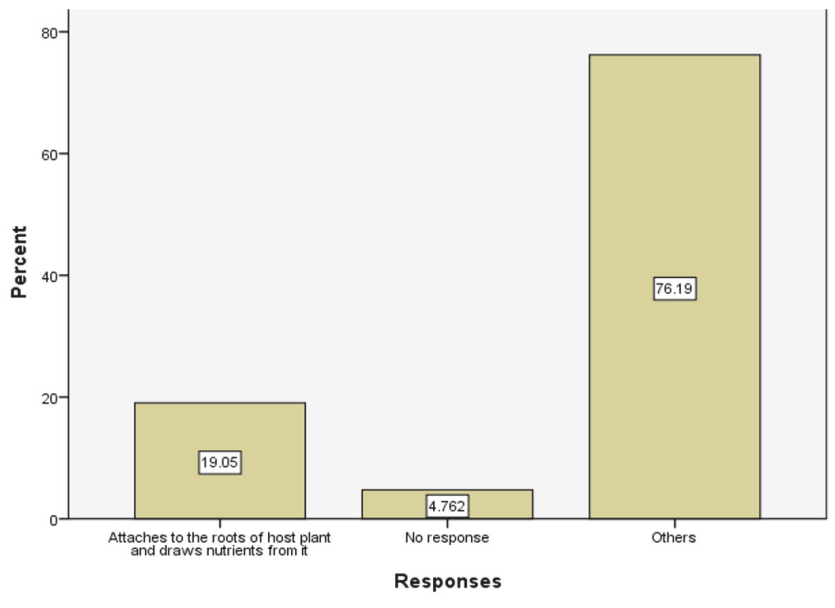

FIGURE 10: How S. gesnerioides affects cowpea plants.

All the farmers (100\%) expressed their readiness to cultivate S. gesnerioides resistant cowpea varieties if only they are supplied with the seeds. Farmers complained of the inaccessibility of quality and S. gesnerioides resistant cowpea seeds, saying that these improved seeds are mostly sold at the regional and district MoFA offices. They added that such seeds are relatively costly, comparing it to those in the public markets. They therefore resort to buying the less costly and available cowpea seeds from the market, not taking into account their susceptibility or resistance to the parasite. The farmers also added that they will be very grateful if their local susceptible cowpea varieties could be improved to be resistant to the parasite. To the farmers, the introduction of more $S$. gesnerioides resistant cowpea varieties and possible introduction of Striga resistance into their local susceptible varieties could put them back in business as the devastating effects of S. gesnerioides were pushing most of them out of business.

According to the AEOs, more than one method is employed by farmers within their areas of supervision in controlling the S. gesnerioides. The methods include weeding or hand picking and the application of manure. They were of the view that these methods employed by farmers are not effective in controlling the parasitic weed. Majority of them (42.9\%) said that the most effective, environmentally friendly, 


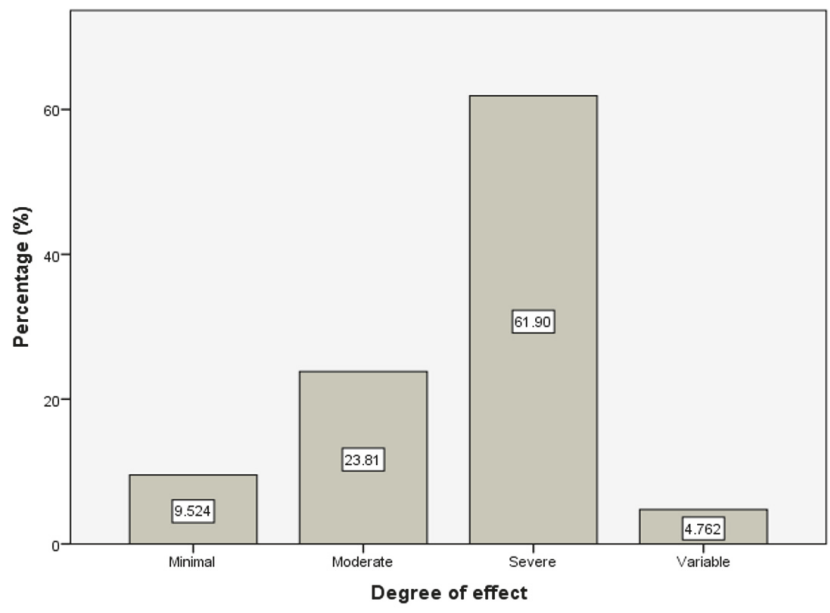

FIGURE 11: Responses of agricultural extension officers (AEOs) on the degree of $S$. gesnerioides infestation of cowpea plants.

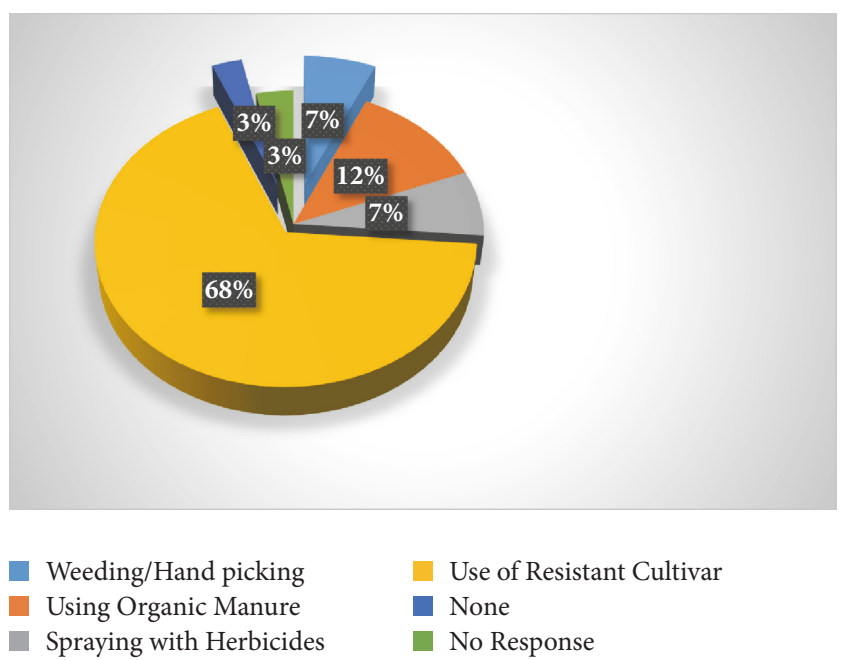

Figure 12: Effective ways of controlling S. gesnerioides.

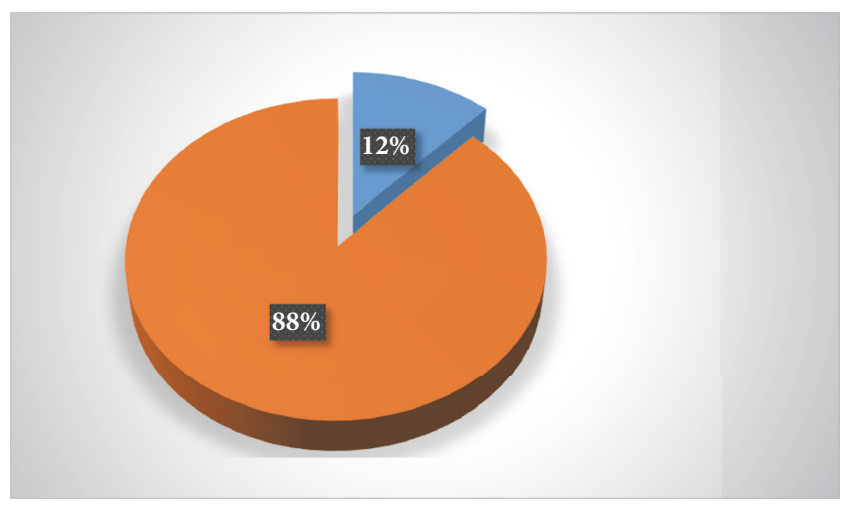

Aware

Not Aware

FIGURE 13: Awareness of the existence of Striga-resistant cowpea varieties.

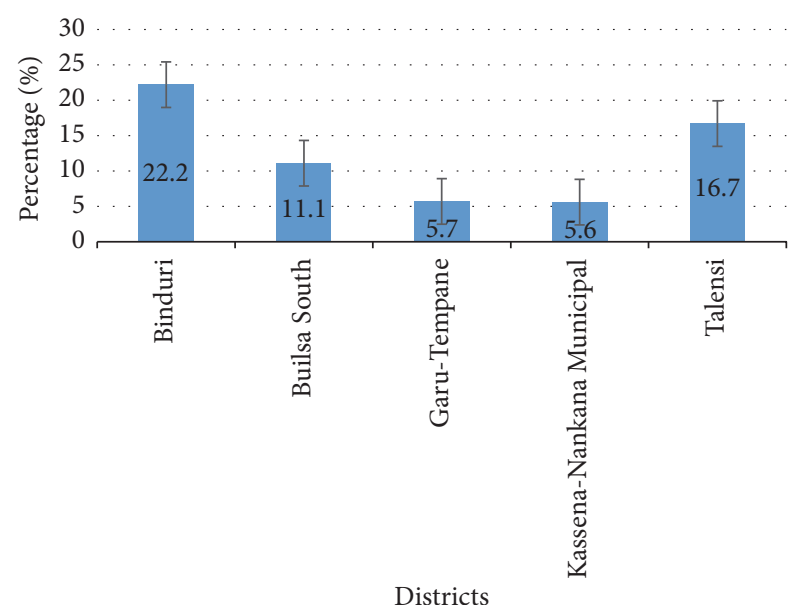

FIGURE 14: Distribution of farmers awareness of S. gesnerioides resistant cowpea varieties in the district.

TABLE 5: Methods of controlling S. gesnerioides by the agricultural extension officers (AEOs).

\begin{tabular}{lcc}
\hline Method & Number of AEOs & Percent (\%) \\
\hline Weeding & 9 & 42.9 \\
Using organic manure & 3 & 14.3 \\
Spraying with herbicides & 1 & 4.8 \\
Use of resistant cowpea & 8 & 38.1 \\
Total & 21 & 100.0 \\
\hline
\end{tabular}

and cost efficient way of controlling the parasitic weed, $S$. gesnerioides, was by weeding and $38.1 \%$ said it was the use of cowpea varieties that are resistant to the S. gesnerioides in their farms (Table 5).

All the AEOs unanimously agreed that farmers within their areas of supervision should be encouraged to cultivate Striga-resistant cowpea varieties in their farms, as it is the most effective approach to curb the devastating effect of $S$. gesnerioides on cowpea farms. This is contrary to their earlier response and choice for weeding as the most appropriate method of controlling the parasite by majority of the AEOs. They also agreed that local susceptible cowpea varieties, such as Apagbaala, Bengpla, and "Alan Cash", which are so cherished by the local farmers could be improved to become resistant to the parasitic weed. The University of Cape Coast, Savannah Agriculture Research Institute (SARI), and Crop Research Institute of the Council for Scientific and Industrial Research in collaboration with the Ministry of Food and Agriculture should help introgress S. gesnerioides resistance into farmers preferred cowpea varieties.

On the importance of $S$. gesnerioides, majority of the AEOs (87\%) were of the view that S. gesnerioides was a serious enemy and had no use to them. A few of the AEOs (13\%) recalled that $S$. gesnerioides was used as mosquito repellant in time past (Figure 15). Despite the fact that S. gesnerioides had some uses, the AEOs emphasized that there was no need for S. gesnerioides to be preserved. They added that everything should be done to eliminate $S$. gesnerioides from the farms 


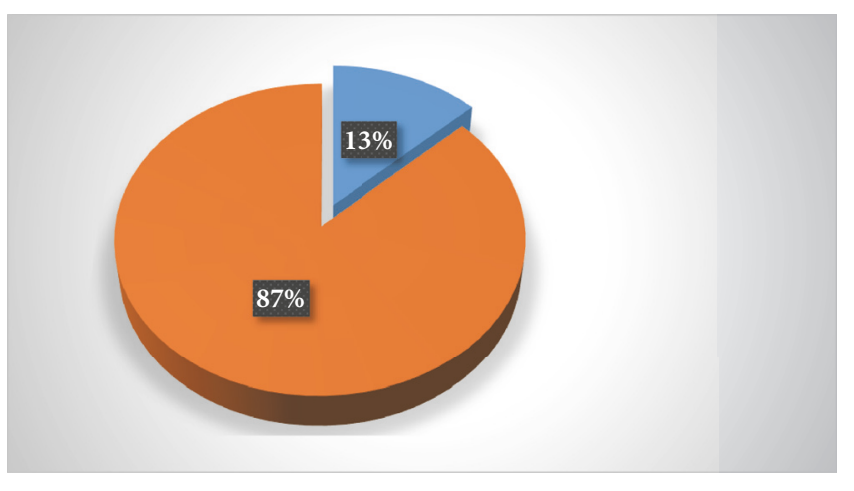

Important

Not Important

FIGURE 15: Importance of S. gesnerioides.

to boost maximum cowpea production in the Upper East Region, which is the poorest region in Ghana.

\subsection{Farmers' Request}

(i) Farmers appealed to all stakeholders in the agriculture sector to help them deal with the prevailing $S$. gesnerioides problem in their farms.

(ii) Farmers requested for more S. gesnerioides resistant cowpea varieties to be made available for cultivation.

(iii) Farmers also called for assistance to improve upon the cultivation of cowpea as it is the major source of protein to most people in the region.

(iv) Farmers requested for introgression of the Strigaresistant gene into their locally preferred cowpea varieties especially "Alan Cash".

\section{Discussion}

4.1. Demographic Data. Generally, more males were involved in cowpea cultivation in the Upper East Region than females. The observed $60 \%$ male cowpea farmers who were married appeared contrary to the report by [26] that $57 \%$ females were involved in the cultivation and utilization of Bambara beans compared to $43 \%$ males in the Sumbrugu community of Bolgatanga. However, report from the Production Survey for the northern regions of Ghana in 2014 showed that $90 \%$ of farmers in the northern regions were males and only $10 \%$ were females [27]. Over $70 \%$ of the farmers were between the ages of 20 and 50. This indicates that a good number of the youth were involved in cowpea cultivation and agriculture as a whole in the region. This is in line with the national cry for the youth employment in agriculture, to increase food production and reduce poverty.

English is important for individuals' long-term economic wellbeing because it is Ghana's official language [27]. Whilst significant effort is being made by the government to enhance formal education in the country, over $85 \%$ of the farmers in the Upper East Region of Ghana had either no formal education or very low formal education (primary education).
They could therefore not speak English or write in English. This could affect their ability to access important information in English to facilitate cowpea production as they cannot read simple instructions on chemicals, fertilizers, and other inputs. Manuals from training workshops cannot be easily used by farmers because of illiteracy. It has been reported that only $12.5 \%$ of 526 farmers in the northern regions of Ghana could read and write in English [27]. The agriculture sector in the region is dominated by the illiterates. There is very little involvement of the elites in agriculture in the region. This could be a very serious challenge to agricultural production in the region and Ghana at large. However, adult literacy evening community classes for farmers could improve the current situation significantly.

4.2. Knowledge and Management of S. gesnerioides. The study revealed that, generally, the knowledge level of both the farmers and AEOs on the parasitic weed, S. gesnerioides, was inadequate. Even though they knew the plant parasite, majority of them (Table 3 and Figure 9) did not know that it is in fact host specific and that it affects only cowpea but not cereals such as maize, sorghum, millet, and rice. They did not also know how the parasitic weed affects its host. This could be attributed to the high illiteracy levels among the farmers in the region, as most of them have no or very little formal education. Majority of the farmers and AEOs were also less experienced in the cultivation of cowpea. Most of them had only 1-5 years of experience in cowpea cultivation. This could also affect their knowledge on the parasitic weed. Poor knowledge in these areas could affect the management and control of the parasite as it could be easily considered as an ordinary weed.

On the whole, it was obvious that the farmers had better knowledge of the parasitic weed than the AEOs in the Upper East Region probably due to their regular encounter with $S$. gesnerioides on their farms. The AEOs in the KassenaNankana Municipal had better knowledge of the parasitic weed, S. gesnerioides, than the other districts. All the four (4) AEOs from the Kassena-Nankana Municipal knew that the parasitic weed S. gesnerioides attaches to the roots of its host plant, cowpea, and draws saps from the plant, which none of the AEOs from the other districts knew. Again two of the three AEOs who knew that S. gesnerioides was host specific and affects cowpea only were from the Kassena-Nankana Municipal.

Farmers knew the time of emergence of the parasite and time of severe infestation on the host. They almost unanimously agreed that $S$. gesnerioides emerges, close to the flowering stage of the host plants, and the severe effects on the host plants are around the fruiting stage. This finding is consistent with that of [28] who reported an average of 40 days for $S$. gesnerioides emergence in pot experiment. It has been reported that $S$. gesnerioides emerged in a pot experiment at 29 days after planting [29].

Symptoms displayed by cowpea due to $S$. gesnerioides infestation include premature leaf senescence, defoliation, chlorosis, necrosis, stunted growth, reduction in surface area of leaves, wrinkling of younger leaflets, poor flowering, or no flowering and fruiting at all [28]. Similarly, in the present 
study the respondent farmers and AEOs mentioned stunted growth, yield loss, and death of the host plant as some of the symptoms of $S$. gesnerioides on the host plant.

Majority (over 95\%) of the farmers and AEOs indicated that S. gesnerioides infestation on cowpea was severe, causing between $80 \%$ and $100 \%$ yield losses, which is comparable to the yield losses of $83-100 \%$ reported elsewhere [20,30,31]. Despite the devastation effects of the S. gesnerioides on crops in the Upper East Region, farmers do not have any effective control measure for S. gesnerioides. The mode of management of $S$. gesnerioides by farmers in the Upper East Region is mostly by weeding using the hoe or by uprooting with the hands. Even though the majority of the farmers knew that application of manure to the soil and intercropping with cereals could help manage the parasitic weed, they said those methods were ineffective. According to them it takes longer time to achieve any appreciable control of the parasitic weed when manure application and intercropping with cereals were adopted.

In fact, majority of the farmers agreed that the most effective way to overcome these parasitic weeds is to cultivate resistant cowpea varieties, whilst the AEOs emphasized weeding, which underscores the fact that AEOs in the region do not know the life cycle of the parasite. Most of the effect of the $S$. gesnerioides occur underground before it emerges and by the time the parasite emerges, the destruction might have been done. Weeding is therefore not the appropriate method of controlling the parasitic weed. The most effective, environmentally friendly, and cost efficient way of controlling the parasitic weed, $S$. gesnerioides, is by cultivating resistant cowpea varieties $[28,32]$.

Most of the farmers (87.7\%) however did not know that there exist S. gesnerioides resistant cowpea varieties for cultivation. Only few farmers from the Binduri and Talensi districts of the region were aware of $S$. gesnerioides resistant cowpeas. These farmers were exposed to S. gesnerioides resistant cowpea demonstration fields by SARI-Manga Station and Cowpea Innovation Laboratory in the Binduri and Talensi districts, respectively, during the 2016 farming season. There were also some demonstration fields of $S$. gesnerioides resistant cowpea varieties in the Builsa South district. These demonstration fields in the region gave the farmers the opportunity to have knowledge of $S$. gesnerioides resistant cowpea varieties even though most of them had never cultivated the improved varieties. Few of the farmers also had knowledge of $S$. gesnerioides resistant cowpea varieties through a workshop organized for cowpea farmers in 2014 by the Upper East Regional Ministry of Food and Agriculture (MoFA). Both farmers and AEOs desire to cultivate and to encourage others to use S. gesnerioides resistant cowpea varieties. Such positive attitudes of the AEOs and farmers towards adoption of S. gesnerioides resistant cowpea varieties will facilitate their adoption by other farmers in the region.

Therefore various district directorates of MoFA in the Upper East Region would have to introduce S. gesnerioides resistant cowpea variety to the farmers when accessible in order to improve productivity. Despite the fact that SARI has released some Striga-resistant cowpea varieties, much effort is needed to make seeds available to farmers to cultivate.
Farmers and agriculture extension officers have to be well informed through both formal and informal education, radio, and television programmes on the need to cultivate Strigaresistant cowpeas in Northern Ghana to improve cowpea production and control the parasitic weed from further spreading down-south. It has been observed that improved cowpea seeds supplied by MoFA were sometimes lost due to poor storage methods employed by farmers [33]. In this respect, farmers have to be trained to adopt the Purdue Improved Cowpea Storage (PICs) techniques to complement the conventional methods to conserve cowpea seeds.

The introduction of $S$. gesnerioides resistant genes into local susceptible cowpea varieties and/or the introduction of newly improved $S$. gesnerioides resistant cowpea varieties to farmers will go a long way to put farmers back in business, as the devastating effect of $S$. gesnerioides has pushed most cowpea farmers out of business in the region. Currently, there is on-going target farmer participatory based breeding programmes in the University of Cape Coast (UCC) and the Savannah Agriculture Research Institute (SARI) to develop diverse Striga-resistant varieties of cowpea to meet farmer and consumer preference. However, the research institutions and the Ministry of Food and Agriculture need to collaborate with seed producing companies to multiply the existing S. gesnerioides resistant cowpea varieties and make them accessible to resource-poor farmers in all S. gesnerioides infested areas of Northern Ghana. In addition, there must be a policy to ensure that only Striga-resistant cowpea varieties are cultivated in the affected regions to facilitate the control of $S$. gesnerioides in Ghana.

\section{Conclusions}

The agriculture sector in the Upper East Region is dominated by farmers who have no or very little formal education. There is very little involvement of the elites in agriculture in the Upper East Region of Ghana. Farmers and agriculture extension officers in the Upper East Region have little knowledge on S. gesnerioides parasitism of host cowpea plant, management, and control as well as $S$. gesnerioides resistant cowpea varieties. S. gesnerioides infestation was widespread and devastating in almost all the farms surveyed. Different management strategies employed by the farmers to contain the spread of the parasite include weeding (90\%), application of manure (5.5\%), and crop rotation and fallowing (4.0\%). Both farmers and extension officers had very little knowledge on existence of $S$. gesnerioides resistant cowpea genotypes for cultivation. However, farmers expressed the desire to cultivate $S$. gesnerioides resistant cowpea varieties to control the parasitic weed.

\section{Data Availability}

The data used to support the findings of this study can be accessed from the corresponding author upon request.

\section{Disclosure}

The authors take full responsibility for any error. 


\section{Conflicts of Interest}

The authors declare that there are no conflicts of interest in relation to publication of this research paper.

\section{Acknowledgments}

The sponsors of the project are the International Treaty on Plant Genetic Resources for Food and Agriculture (ITPGRFA) and the Food and Agriculture Organization (FAO). We are indeed grateful to ITPGRFA and FAO for sponsoring this research.

\section{References}

[1] I. Singh, S. N. Badaga, and S. B. S. Tikka, "Combining ability for yield over environments in cowpea (Vigna unguiculata L. Walp)," Indian Journal of Crop Science, vol. 1, no. 2, pp. 205-206, 2006.

[2] Y. P. Gupta, "Pulse crops," in Nutritive Value of Pulses, B. Baldev and S. Ramanujam and H, Eds., p. 563, Nutritive Value of Pulses, 1998.

[3] S. A. Tarawali, B. B. Singh, S. C. Gupta, R. Tabo, and F. Harris, "Cowpea as a key factor for a new approach to integrated crop livestock systems research in the dry savannas of West Africa," in Challenges and Opportunities for Enhancing Sustainable Cowpea Production, Cowpea Production, IITA, pp. 233-251, Ibadan, Nigeria, 2002.

[4] D. K. Berner and O. A. Williams, "Germination Stimulation of Striga gesnorioides seed by host and non-host," Plant Disease, vol. 82, pp. 1242-1247, 1998.

[5] K. Stahley, E. Slakie, K. Derksen-Schrock, M. K. Gugerty, and C. I. Anderson, "LSMS -integrated surveys on agriculture in united republic of tanzania: legumes," in Evans School Policy Analysis and Research, vol. 189, School Policy Analysis and Research, University of Washington, Washington DC, Wash, USA, 2012.

[6] F. K. Egbadzor, M. Yeboah, S. K. Offei, K. Ofori, and E. Y. Danquah, "Farmers key production constraints and traits desired in cowpea in Ghana," Journal of Agriculture and Rural Development in the Tropics and Subtropics, vol. 5, no. 1, pp. 1420, 2013.

[7] International Crops Research Institute for the Semi-Arid Tropics (ICRISAT), "Cowpea farming in Ghana," Bulletin of Tropical Legumes, 2012, http://www.n2africa.org/sites/n2africa .org/files/images/BTL16-20122712_0.pdf.

[8] R. M. Al-Hassan and X. Diao, "Regional disparities in Ghana: policy options and public investment implications," Ghana Strategic Support Programme," 2007, http://www.ifpri.org/ themes/gssp/gssp.htm.

[9] B. B. Singh and A. M. Emechebe, "Advances in research on cowpea Striga and Alectra," Advances in Cowpea Research, pp. 215-224, 1997.

[10] A. Mbwaga, J. Hella, J. Mligo, V. Kabambe, and J. Bokos, "Development and promotion of Alectra resistant cowpea cultivars for smallholder farmers in Malawi and Tanzania," McKnight Foundation Collaborative Crops Research Project 06741, 2010.

[11] J. Sauerborn, "The economic importance of the phytoparasites, Orobanche and Striga," in Proceedings of the Fifth International
Symposium on Parasitic Weeds CIMMYT, Ransom., J. K. Musselman, L. J. Worsham, A. D. Parker, and C., Eds., pp. 137-143, Nairobi, Kenya, 1991.

[12] L. Victoria, A. Richard, A. Stephen, Y. A. James, P. Ruth, and F. Kusi, "Marker assisted selection for resistance to Striga gesnerioides in Cowpea (Vigna unguiculata L. Walp)," Journal of Bioscience and Biotechnology Discovery, vol. 2, pp. 97-103, 2017.

[13] V. D. Aggarwal and T. J. Ouedraogo, "Estimation of cowpea yield loss from Stiga Infestation," Tropical Agriculture (Trinidad), vol. 66, no. 7, pp. 91-92, 1989.

[14] S. O. Alonge, S. T. O. Lagoke, and C. O. Ajakaiye, "Cowpea reactions to Striga gesnerioides I. Effect on growth," Crop Protection, vol. 24, no. 6, pp. 565-573, 2005.

[15] A. Y. Kamara, D. Chikoye, F. Ekeleme, L. O. Omoigui, and I. Y. Dugje, "Field performance of improved cowpea varieties under conditions of natural infestation by the parasitic weed Striga gesnerioides," International Journal of Pest Management, vol. 54, no. 3, pp. 189-195, 2008.

[16] L. O. Omoigui, M. P. Timko, F. S. Ishiyaku et al., "Molecular characterization of cowpea breeding line for Striga using FTA (Flinders Technology Associations) technology," in Proceedings of the African Crop Science Conference, vol. 9, pp. 527-530, 2009.

[17] S. Alonge, S. Lagoke, and C. Ajakaiye, Cowpea Reactions to Striga gesnerioides: Effect on Growth," Association of Official Analytical Chemist (AOAC), vol. 24, William Hortwits, Washington DC, Wash, USA, 12th edition, 2004.

[18] J. Ram, B. B. Singh, and J. P. Prem, Genetic Resources, Chromosome Engineering, and Crop Improvement, vol. 1, 2005.

[19] I. Y. Dugje, L. O. Omoigui, F. Ekeleme, A. Y. Kamara, and H. Ajeigbe, Famers Guide to Cowpea Production in West Africa, 2009.

[20] K. F. Cardwell and J. A. Lane, "Effect of soils, cropping system and host phenotype on incidence and severity of Striga gesnerioides on cowpea in West Africa," Agriculture, Ecosystems \& Environment, vol. 53, no. 3, pp. 253-262, 1995.

[21] K. I. Mohamed, L. J. Musselman, and C. R. Riches, “The genus Striga (Scrophulariaceae) in Africa," Annals of the Missouri Botanical Garden, vol. 88, no. 1, pp. 60-103, 2001.

[22] C. J. Botanga and M. P. Timko, "Genetic structure and analysis of host and nonhost interactions of Striga gesnerioides (Witchweed) from Central Florida," Journal of Phytopathology, vol. 95, no. 10, pp. 1166-1173, 2005.

[23] A. T. Asare, B. S. Gowda, I. K. A. Galyuon, L. L. Aboagye, J. F. Takrama, and M. P. Timko, "Assessment of the genetic diversity in cowpea (Vigna unguiculata L. Walp.) germplasm from Ghana using simple sequence repeat markers," Plant Genetic Resources, vol. 8, no. 2, pp. 142-150, 2010.

[24] A. A. Abunyewa and F. K. Padi, "Changes in soil fertility and Striga hermonthica prevalence associated with Legume and cereal cultivation in the Sudan savannah zone of Ghana," Land Degradation \& Development, vol. 14, no. 3, pp. 335-343, 2003.

[25] S. Issah, F. Kusi, A. L. K. Roger, K. N. Stephen, and Z. Mukhtar, "Sustaining Frafra Potato (Solenostemon rotundifolius Poir.) in the Food Chain; Current Opportunities in Ghana," Journal of Plant Sciences, vol. 1, no. 4, pp. 68-75, 2013.

[26] M. M. Akpalu, I. A. Atubilla, and D. Oppong-Sekyere, "Assessing the Level of Cultivation and Utilization of Bambara Groundnut (Vigna Subterranea (L.) Verdc.), in the Sumbrungu Community of Bolgatanga, Upper East Region, Ghana," International Journal of Plant, Animal and Environmental Sciences, vol. 3, no. 3, pp. 68-75, 2013. 
[27] V. Amanor-Boadu, Y. Zereyesus, R. Kara et al., "Agricultural production survey for the Northern Regions of Ghana," 20132014 Results," Final Report, 2015.

[28] T. A. Asare, I. K. A. Galyuon, F. K. Padi et al., "Responses of Recombinant Inbred Lines of Cowpea [(Vigna unguiculata (L.) to Striga gesnerioides infestation in Ghana," in Proceedings of the 1st Annual international Interdisciplinary Conference, AIIC, pp. 24-26, Azore, Portugal, 2013.

[29] L. O. Omoigui, M. F. Ishiyaku, B. S. Gowda et al., "Suitability and use of two molecular markers to track race-specific resistance Striga gesnerioides in cowpea (Vigna unguiculata (L.) Walp.)," African Journal of Biotechnology, vol. 14, no. 27, pp. 2179-2190, 2015.

[30] A. M. Emechebe, B. B. Singh, O. I. Leleji, I. D. K. Atokple, and J. K. Adu, "“Cowpea Striga problems and research in Nigeria, Combating Striga in Africa," in Proceedings of the International Workshop Held, S. K. Kim, Ed., pp. 18-28, International Institute of Tropical Agriculture, Ibadan, Nigeria, 1991.

[31] V. Larweh, Introgression of Striga (Striga gesnerioides Willd) Resistance into Cowpea (Vigna Unguiculata L. Walp) Varieties [Master Thesis], University of Science and Technology, Kumasi, Ghana, 2016, http://dspace.knust.edu.gh/handle.

[32] L. O. Omoigui, A. Y. Kamara, F. S. Massawe et al., "Evaluation of cowpea genotypes for their reactions to Striga gesnerioides in the dry savannah of northern Nigeria," in Proceedings of the African Crop Science Conference, vol. 8, pp. 273-278, 2007.

[33] B. L. Yakubu, O. A. Mbonu, and A. J. Nda, "Cowpea (Vigna unguiculata) pest control methods in storage and recommended practices for efficiency: a review," Journal of Biology Agriculture and Healthcare, vol. 2, no. 2, pp. 27-33, 2012. 


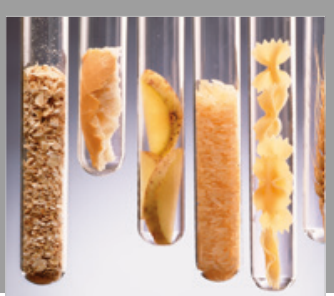

International Journal of Food Science

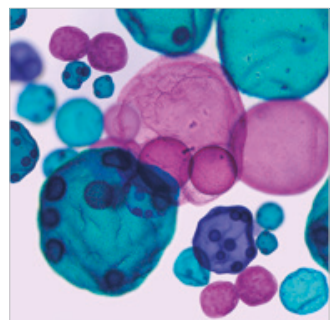

International Journal of Microbiology
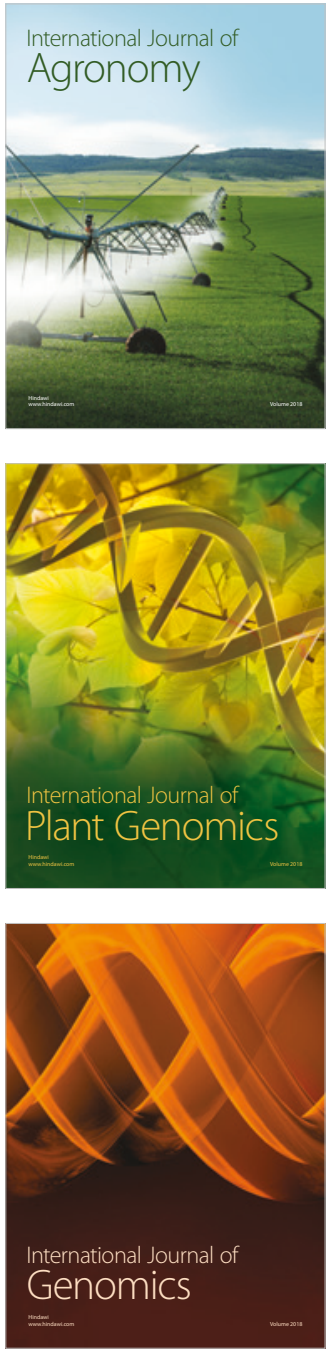

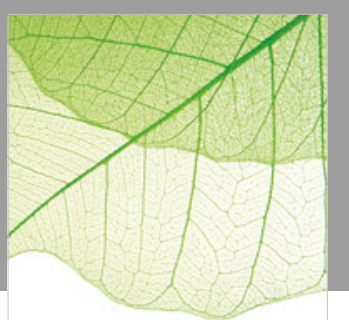

Journal of Botany
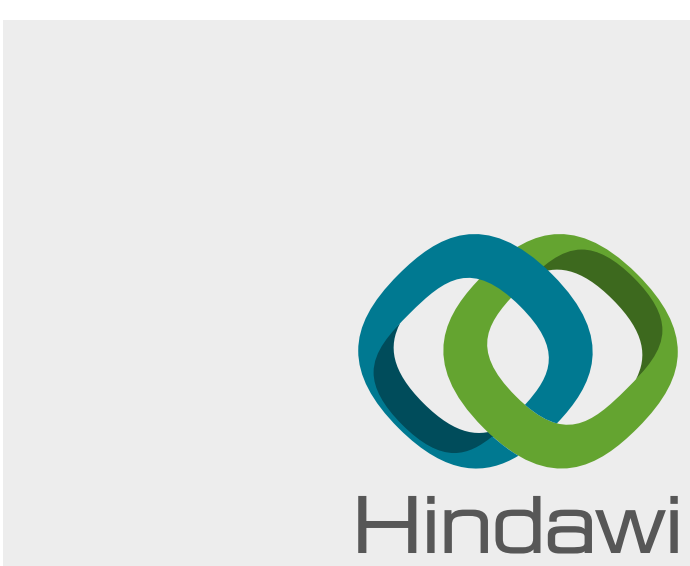

Submit your manuscripts at

www.hindawi.com
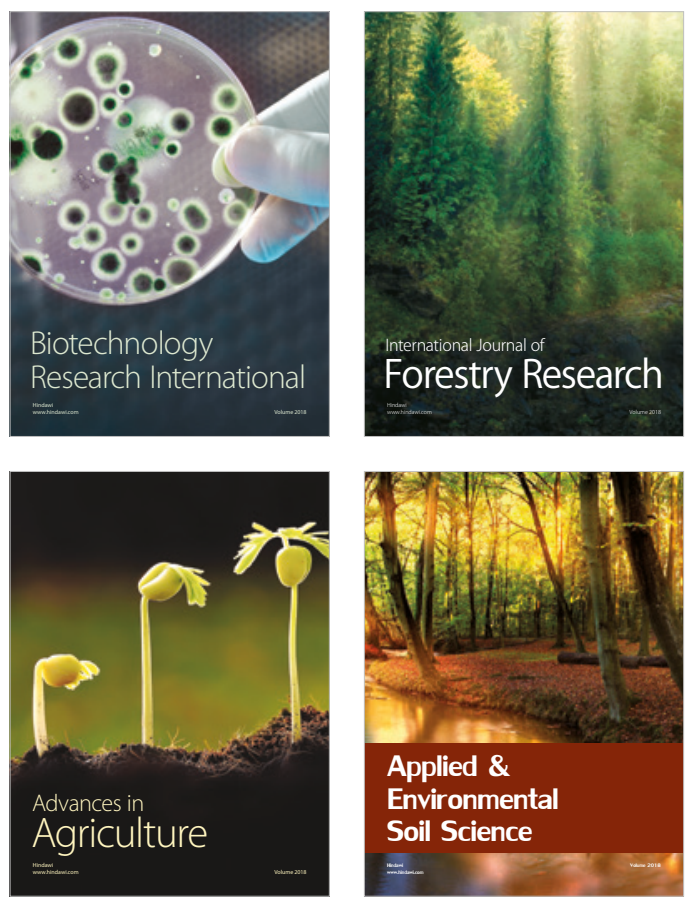

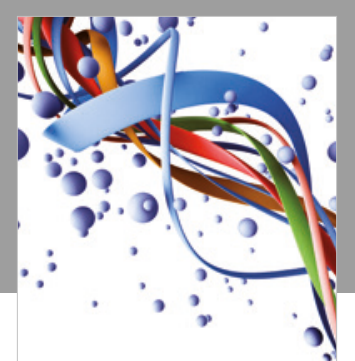

Scientifica

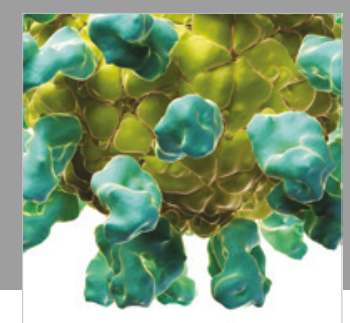

Veterinary Medicine International

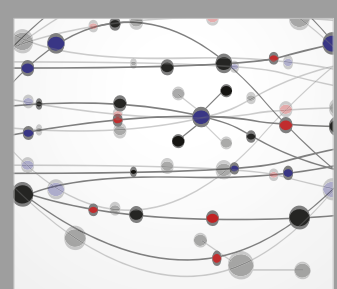

The Scientific World Journal
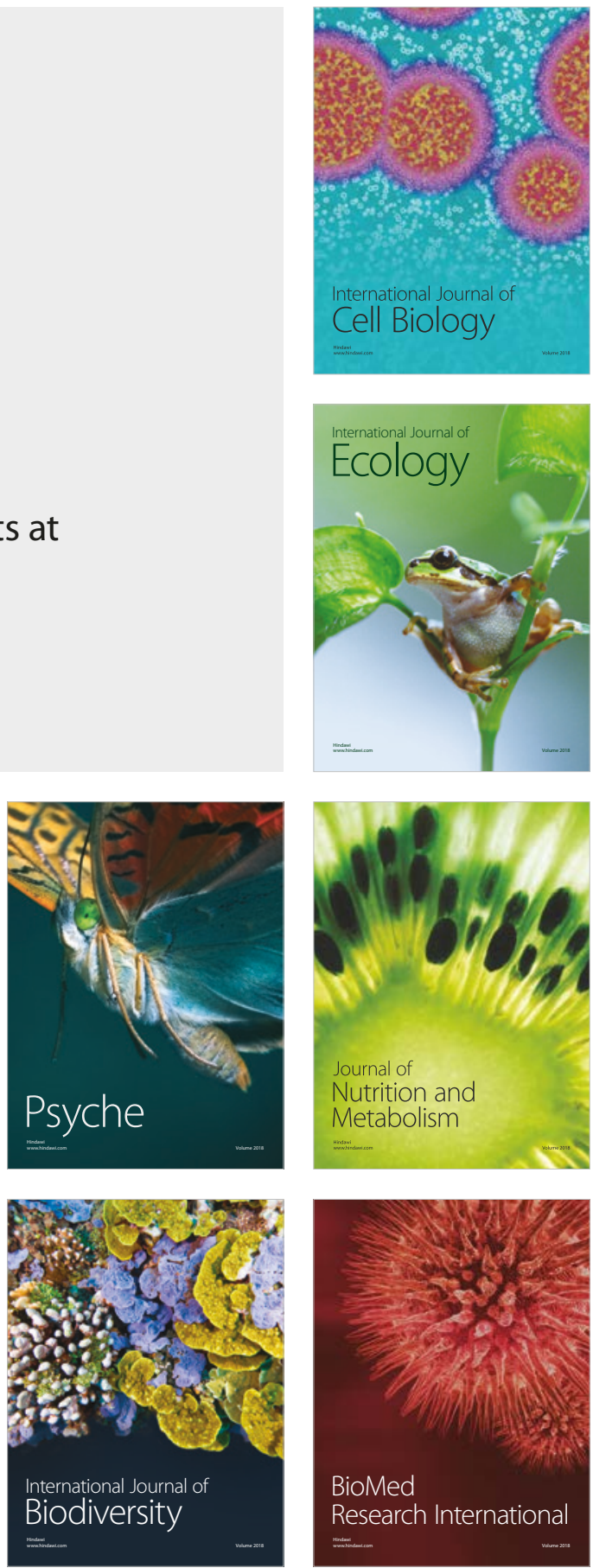